\title{
PENGARUH EKSTRAK ETANOL BUNGA KECOMBRANG (Etlingera elatior) TERHADAP PENYEMBUHAN LUKA PADA TIKUS PUTIH (Rattus novergicus)
}

\author{
Josanti Pitri Sagala*, Wisnu Cahyo Prabowo, Rolan Rusli \\ Laboratorium Penelitian dan Pengembangan FARMAKA TROPIS \\ Fakultas Farmasi Universitas Mulawarman, Samarinda, Kalimantan Timur \\ *email: josantisagala@gmail.com
}

\begin{abstract}
ABSTRAK
Bunga Kecombrang (Etlingera elatior) adalah tanaman yang banyak tumbuh di Indonesia. Tanaman ini termasuk ke dalam Zingiberaceae. Umumnya masyarakat menggunakan bunga kecombrang sebagai bumbu masakan, mengobati sakit telinga dan daunnya juga dapat digunakan untuk menyembuhkan luka. Penelitian ini bertujuan untuk mengetahui pengaruh ekstrak etanol bunga kecombrang terhadap penyembuhan luka pada tikus putih. Pengujian ini menggunakan 18 ekor tikus yang dibagi menjadi 6 kelompok. Luka sayat dibuat pada bagian punggung tikus dengan panjang $2 \mathrm{~cm}$ dan kedalaman $2 \mathrm{~mm}$, kemudian diberikan perlakuan sesuai dengan kelompoknya masing-masing 2 kali sehari. Hasilnya adalah pada konsentrasi $15 \%$ terlihat efek penyembuhan luka yang paling cepat yaitu 8 hari sedangkan pada kelompok Povidone Iodine penyembuhan luka terjadi pada hari ke-10, sehingga ekstrak bunga kecombrang berpotensi sebagai obat luka.
\end{abstract}

Kata kunci : Bunga Kecombrang, Luka, Tikus Putih

\begin{abstract}
Kecombrang flower (Etlingera elatior) ia a plant that grows in Indonesia. This plant included in Zingiberaceae. Generally, people use kecombrang as a cooking flavor, treat earache and leaves also used to heal wounds. The aim of this research was to determine the effect of ethanol extract of Kecombrang flower on wounds healing in rats. This test was used 18 rats that divided into 6 groups. The wounds was made on the back of rats with a length of $2 \mathrm{~cm}$ and the depth of $2 \mathrm{~mm}$, then the treatment was given twice a day. The result shown that at concentration $15 \%$ was the fastest wound healing at 8 days, while Povidone Iodine groups wound healing on day 10. Extract kecombrang flower is potential as a cure wounds
\end{abstract}

Keywords : Kecombrang flower, Wound, Rats

\section{PENDAHULUAN}

Luka merupakan kerusakan jaringan yang menyebabkan terganggunya proses selular normal dari tubuh, khususnya pada bagian kulit. Dalam kegiatan sehari-hari luka sering ditemukan khususnya pada anak-anak. Luka dibedakan berdasarkan penyebab lukanya, seperti luka bakar, luka sayat, luka tusuk dan lain sebagainya. Menurut data dari MedMarket Diligence, sebuah asosiasi luka di Amerika yang mencatat prevalensi angka kejadian luka dari tahun ke tahun berdasarkan tipe-tipenya, ada lebih dari 100 juta kasus luka pertahunnya, dan angka ini meningkat 4-6\% setiap tahun. Oleh karena itu saat ini 
banyak dikembangkan obat-obat luka yang lebih cepat dalam menyembuhkan luka dan efek sampingnya ringan serta tidak menimbulkan iritasi.

Bunga kebombrang banyak tumbuh di sumatera dan kalimantan. Masyarakat biasanya menggunakan bunga kecombrang sebagai bumbu masakan, mengobati sakit telinga, menghilangkan bau badan dan daunnya sebagai pencuci luka (Chan, 2007).

Bunga kecombrang mengandung flavonoid, terpenoid, saponin, tanin dan karbohidrat seperti alkaloid dan antrakuinon (Jackie, 2011). Bunga kecombrang memiliki aktivitas sebagai antibakteri dengan nilai MIC 1,56-50 $\mathrm{mg} / \mathrm{mL}$ dan antioksidan dengan nilai IC 9,14 mg/mL (Lachumy, 2010).

\section{METODE PENELITIAN}

Penelitian ini merupakan percobaan eksperimental dengan menggunakan 18 ekor tikus yang dibagi kedalam 6 kelompok yang masing-masing kelompok terdapat 3 ekor tikus.

\section{Bahan}

Bunga Kecombrang, Etanol 96\%, povidone iodine, $\mathrm{NaCl}$, Alkohol, kasa.

\section{Peralatan}

Pisau bedah no.24, pisau cukur, penggaris, gunting

\section{Prosedur}

\section{Ekstraksi}

Bunga kecombrang segar diambil dari desa Pampang, Samarinda. Setelah itu dibersihkan dan dikeringkan. Kemudian simplisia yang telah kering dimaserasi dengan menggunakan etanol $96 \%$ dan hasil filtratnya dievaporasi untuk menghilangkan pelarutnya sehingga menghasilkan ekstrak pekat.

\section{Penyiapan Hewan Uji dan Pembuatan Luka}

Hewan yang digunakan adalah 18 ekor tikus yang memiliki berat badan 200-300 gram dan dibagi kedalam 6 kelompok yaitu kelompok 5\%, 10\%, 15\%, 20\% kontrol negatif dan Povidone Iodine. Sebelum dilakukan pembuatan luka, hewan diaklimatisasi selama 2 minggu. Setelah itu punggung tikus dicukur dan dibuat luka sayatan dengan panjang luka $2 \mathrm{~cm}$ dan kedalaman $2 \mathrm{~mm}$. Kemudian, luka diberi ekstrak sesuai dengan kelompoknya masing-masing sebanyak 2 kali sehari dan setiap hari diukur panjang lukanya.

\section{HASIL DAN PEMBAHASAN}

Penyembuhan luka yang paling cepat terdapat pada kelompok ekstrak 15\% yang sembuh dalam waktu 9 hari sedangkan kelompok kontrol negatif sembuh dalam 13 hari dan kelompok kontrol positif yaitu Povidone Iodine sembuh dalam 11 hari. Hal ini menunjukkan bahwa ekstrak bunga kecombrang memiliki pengaruh dalam mempercepat penyembuhan luka (Gambar.1). 


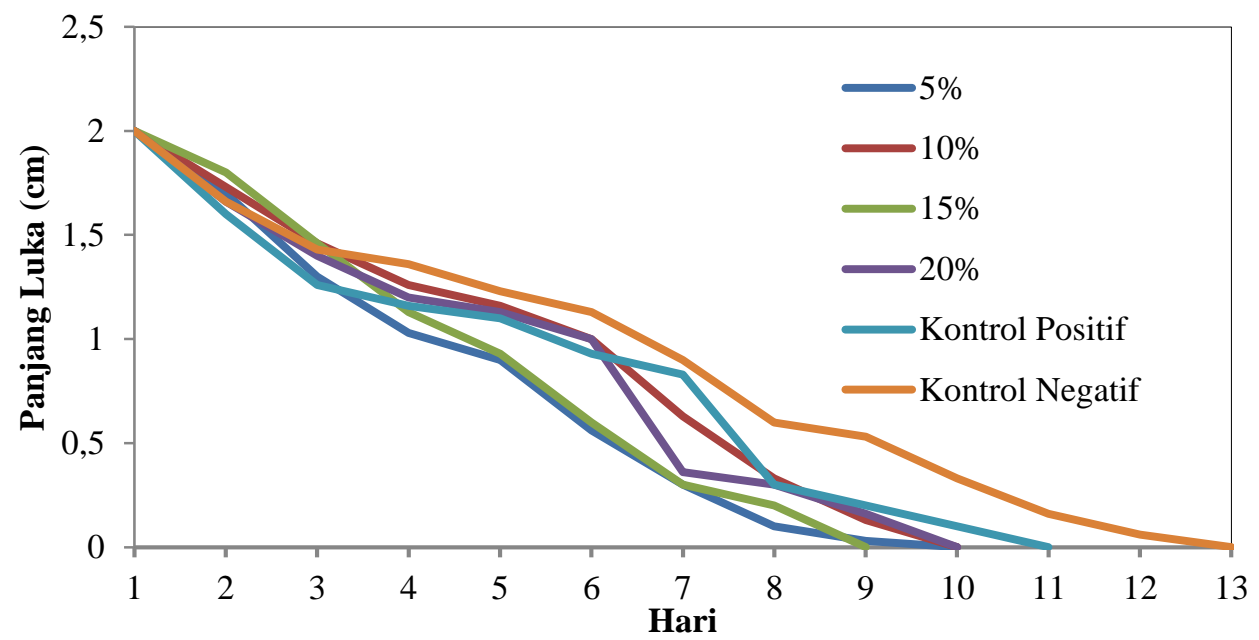

Gambar.1 Grafik Penyembuhan Luka

Hasil pengujian ANOVA dengan menggunakan Uji Duncan terlihat bahwa tidak ada perbedaan yang nyata antara kelompok 5\%, 10\%, 15\%, 20\% dan Povidone Iodine. Hal ini terlihat dari nilai rata-ratanya yang tidak berbeda jauh. Meskipun nilai rata-rata dari kelompok $15 \%$ adalah yang paling besar namun secara statistik tidak menunjukkan adanya perbedaan yang nyata dalam hal kemampuan penyembuhan luka jika dibandingkandengan kelompok 5\%, 10\%, 20\% dan Povidone Iodine. Dari hasil tersebut dapat terlihat bahwa konsentrasi yang paling efektif dalam menyembuhkan luka adalah konsentrasi 5\% karena dengan konsentrasi yang kecil sudah dapat menimbulkan efek penyembuhan luka yang sama pada konsentrasi $15 \%$. Dari hal tersebut dapat diketahui pula bahwa potensi ekstrak bunga kecombrang dalam menyembuhkan luka sama dengan povidone Iodine (Tabel.1)

Tabel.1 Hasil Analisis Statistik Duncan pada Rata-Rata Kecepatan Penyembuhan Luka

\begin{tabular}{lcccc}
\hline \multirow{2}{*}{ Kelompok } & \multirow{2}{*}{$\mathrm{N}$} & \multicolumn{2}{c}{ Subset } \\
\cline { 3 - 4 } Kontrol Negatif & 36 & 1,2083 & & 2 \\
$10 \%$ & 36 & & 1,3556 & \\
$20 \%$ & 36 & & 1,3972 & \\
Povidone & 36 & & 1,4111 & \\
$5 \%$ & 36 & & 1,4528 \\
$15 \%$ & 36 & & 1,4722 \\
\hline Sig. & & 1,000 &, 083 \\
\hline
\end{tabular}

Means for groups in homogeneous subsets are displayed.

Based on observed means.

The error term is Mean Square(Error) $=, 064$.

a. Uses Harmonic Mean Sample Size $=36,000$.

b. Alpha $=, 05$.

Berdasarkan penelitian sebelumnya mengenai metabolit sekunder dari bunga kecombrang adalah flavonoid, terpenoid, saponin, tanin dan karbohidrat seperti alkaloid 
dan antrakuinon. Metabolit sekunder inilah yang diduga berperan dalam mempercepat proses penyembuhan luka.

Penyembuhan luka secara umum dibagi menjadi tiga fase yaitu fase inflamasi, proliferasi dan maturasi/remodelling. Segera setelah terjadinya luka, pembuluh darah yang putus akan mengalami konstriksi yang disertai dengan reaksi hemostasis dimana trombosit yang keluar dari pembuluh darah akan saling melengket dan benang-benang fibrin akan membentuk bekuan darah sehingga perdarahan berhenti (Sherwood, 2001).

Setelah itu terjadilah fase inflamasi yang ditandai dengan gejala seperti kemerahan, nyeri, panas, dan pembengkakan pada luka. Dalam fase ini, sel mast akan mengeluarkan mediator-mediator inflamasi yang ikut menghancurkan bakteri pada luka. Selanjutnya adalah fase proliferasi yaitu fase regenerasi sel-sel mati. Kemudian fase maturasi/remodelling dimana terjadi proses pematangan sel-sel baru hingga luka akhirnya sembuh.

Flavonoid merupakan antioksidan yang mencegah oksidasi pada sel sehingga kerusakan sel dapat dihambat. Selain itu flavonoid juga berperan sebagai antiinflamasi dan meningkatkan kecepatan epitelisasi sehingga membantu mempercepat penyembuhan luka.

Tanin berperan sebagai antibakteri dan adstringen yang menyebabkan penciutan pori-pori kulit. Saponin juga berperan sebagai antibakteri yang mencegah pertumbuhan mikroorganisme sehingga luka tidak mengalami infeksi yang berat (Yenti, 2011). Selain itu saponin juga berperan dalam menstimulai sel-sel baru dan jaringan kulit (Kurniati, 2008).

\section{KESIMPULAN}

Ekstrak bunga kecombrang memiliki pengaruh dalam mempercepat penyembuhan luka dengan dosis efektif sebesar 5\%. Ekstrak bunga kecombrang memiliki potensi yang sama dalam menymbuhkan luka jika dibandingkan dengan Povidone Iodine.

\section{DAFTAR PUSTAKA}

1. Chan et al. 2007. Antioxidant and antibacterial activity of leaves of Etlingera species (Zingiberaceae) in Penisular Malaysia. Food Chemistry 104, 1586-1593.

2. Jackie et al. 2011. Antioxidant Effects of Etlingera elatior Flower Extract Against Lead Acetate-Induced Pertubations in Free Radical Scavenging Enzymes and Lipid Peroxidation in Rats. BMC Research Notes 4, 67

3. Lachumy et al. 2010. Pharmacological Activity, Phytochemical Analysis and Toxicity of Methanol Extract of Etlingera Elatior (torch ginger) Flowers. Asian Pasific J of Tropical Medicine. 769-774

4. Shewood, L. 2001. Human Physiologi From Cells to System $5^{\text {th }}$ ed. Thomson LearningBrooksdale Cole. New York.

5. Yenti et al. 2011. Formulasi Krim Ekstrak Etanol Daun Kirinyuh (Euphatorium odoratum. L) untuk Penyembuhan Luka. Majalah Kesehatan PharmaMedika. 3 (1) . 227-230

6. Kurniati, 2008. Efek Ekstrak Etanol Daun Flamboyan (Delonix regia Raf.) Terhadap Penyembuhan Luka Bakar Pada Kelinci (Oryctolagus cuniculus). Universitas Hasanuddin Makassar. 